\title{
Applications of Educational Serious Games for Information Technology Related Subjects in Higher Education
}

\author{
Afrooz Purarjomaldlangrudi \\ Faculty of Science and Engineering, Queensland University of technology (QUT) \\ Brisbane, Queensland, 4000, Australia \\ E-mail:a.purarjomandlangrudi@qut.edu.au \\ Amir Hossein Ghapanchi \\ School of Information and Communication Technology, Griffith University \\ Gold Coast, Queensland, 4222, Australia \\ AND \\ Institute for Integrated and Intelligent Systems \\ Gold Coast, Queensland, 4222, Australia \\ E-mail: a.ghapanchi@griffith.edu.au
}

\begin{abstract}
Serious games which are designed for purposes rather than pure entertainment have become one of the popular topics these days as they have the potential to be effective and efficient teaching tools which are interactive, attractive and immersive. This study conducts a systematic literature review on the past research on the application of educational serious games in Information Technology (IT) related subjects in tertiary sector, and aims at broadening our understanding of the role of games in education. Herewith, we searched the selected keywords on several academic databases and found an initial set of 3437 studies. Then we excluded papers on the basis of their title, abstract and full text to come up with a set of more relevant studies. This paper proposes a new classification for applied games in this area and classifies them into five categories of simulation games, puzzle-solving games, $3 D$ games, board games, and role-playing games. The results of the data analysis show that majority of the studies have used simulation and role-playing games. A summary of the results and conclusions of each paper is also provided to inform both teachers and researchers on the topic.
\end{abstract}

Keywords: serious game, information technology, information systems, computer, e-learning, university.

\section{Introduction}

“Serious Game” (SG) or “applied game” refers to a type of game which is designed to improve specific aspects of learning and teaching. In concept, they are simulations of real-world events or proceedings designed for the problem solving purposes. They can be applied to a broad spectrum of application like healthcare, emergency management, education, city planning, engineering and so forth. Nowadays, this is considered as a serious business and the market for $S G s$ is worth $\$ 20$ million while digital games is a $\$ 10$ billion per year industry ${ }^{[1]}$, and it is also expected to grow up over the next decade. In terms of education, they can be found at every level of education, at all kinds of schools and universities around the world. Serious games are considered very important in the global education and training market, which was estimated to be worth \$2 trillion in $2003^{[2]}$.

Serious games in education or games-based learning $(G B L)$ facilitate the teaching and learning by simulating the real process and provide the learners with the ability to experience situations that are not easy to deal with in the real environment. The motivating and engaging features of games, teamwork experiences, decision making and suggestions that players might develop in 
the game procedure are some positive features that have made the SGs considered as efficient and attractive, new methods of learning-by-doing. Students will be encouraged to learn different concepts and practice them in an entertaining and interesting environment, and then they will be able to transfer their knowledge and learning outcomes to the real educational environment. Gaming as an educational tool has been used since 1900s and paper-based games were very interesting in 1960s and 1970s ${ }^{[3]}$. Regarding Information Technology (IT) subjects, the majority of research has been conducted in the 2000s. In 1997,T. Savolainen ${ }^{[4]}$ offerd two simulation games in computer Integrated Manufacturing (CIM) called "project managementsimulation game”, (PMSG), and “business process simulation game”, (BPSG). The games were arranged in all cases and they lasted about an hour and after each session people answered some questions. A. Martin[5] designed and developed a game named "THE MIS” for teaching information systems development subject. The content of the game contains the project management and traditional information systems development life-cycle concept. The game offers a variety of practical eventualities of information systems development, such as disasters, audits, staff turnover, technical problems, user resistance, and etc.Althoughthere are severalstudies on SGs and GBL, however, there is no systematic review on application of them in IT subjects.

In order to fill the above-mentioned gap, the aim of the present study is set to provide a comprehensive literature review on academic papers which have studied SGs in IT related subjects. This systematic method could help us to establish the trends in literature with regard to application of SGs in these courses, as well as the major research gaps. To do so, we searched in eight academic databases and came up with 21 relevant studies in the field of IT which applied and evaluated different types of games. Through this review, we made an attempt to answer the following research questions:

- RQ1. What are the demographic characteristics of the papers which have dealt with serious games for IT related subjects?

- RQ2. What evaluation methods are applied? And, what games are used in the literature for IT subjects?
- RQ3.What is the classification for these games?

The results of this paper could be beneficial for future researchers in terms of a better understanding of the field, classifying their research and ascertaining any research gaps. It would also benefit IT instructors and teachers by providing a short introduction and directing them to the correct area that may solve their teaching problems.

The remainder of this paper is organized as follows: section 2 provides an overview of previous literature reviews on adopting serious games in IT subjects. Section 3 describes our research methodology and our criteria for including and excluding studies. Section 4 provides the results of the systematic literature review and the proposed classification. We discuss the results of the study in Section 5, and provide some recommendations for future research. Concluding remarks are provided in section 6 .

\section{Research Background}

Although there are several research on the application of SGs in different aspects of educations, there is a lack in studies that review and analyze the research focused on applying SGs in IT related subjects. A very first article on the topic was published by $T$. Savolainen $^{[4]}$ which designed two games, PMSGandBPSG, for CIM subject. The game was plyedwith fivedifferent group of student in one-of-akind plant project business, in flexible series manufacturing business and in mass production business in different phases of the CIM-projects. In the PMSG the life cycle of a generic one-of-a-kind delivery project is fully simulated with a few duration sample dates of the project. In the BPSG the main business process chains of the whole company are simulated at a rough level.

In 2000, A. Martin[5] represented “THE MIS” game for information systems development topic. The content of the game designed around the project management and traditional information systems development. A. Y. Chua in 2005[6] present a game called The Chief Knowledge Officer(CKO) in Knowledge Management concept. In CKO participants face issues related to knowledge management and learn how their decisions could affect the outcome of the company. Players are grouped into knowledge management teams to assist the 
Chief Knowledge Officer of a company to go through eight business cycles of decision making.

T. M. Connollyet al.[7] used an online games-based learning approach for teaching database designing concept. There are 3 levels that form the learning environment: 1-online learning units/topics, 2visualizations, and 3-The simulation game. Levels 1 and 2 of the environment have been developed and initial findings are positive. A Chi-squared test using the crosstab frequencies was conducted and the result showed that a games-based learning environment can highly impact the learners' skills. In 2006 P.M. Léger[8] introduce "SAP R/3" which is a simulation game to tech Enterprise Resource Planning (ERP) topic.The game was conducted among five groups of students. All of the students in the companies are involved in the manufacturing and distribution of muesli cereals to practice the concept of ERP.

Regarding Decision Support System (DSS) subject, T. Ben-Zvi ${ }^{[9]}$ introduced a game called "NITOPIA" that the main purpose of the game is to increase students' understanding of strategic management of international operation. The students practice their own DSS development in the game and the simulation forces them to think for themselves and generate their own learning. Another paper in this filed that published in 2007 was $^{[10]}$ in which the author designed a role-play game named "SDSim" to teach software engineering subjects. The main idea of the game is for the team to manage and deliver a number of software development projects. Different roles assigned to the player such as project manager, systems analyst, systems designer or team leader.

C. Kazimogluet al. ${ }^{[11]}$ developed a puzzle-solving game for computational thinking and learning traditional programming. The players control a character and help him to reach specific destination points by giving different commands to the character. They can give two types of commands to their player character: action commands and programming commands. M. Muratet et al. ${ }^{[12]}$ represented "Prog\&Play" which is a role-play game for computer programming (CP) concepts. It is based on an open source real-time strategy (RTS) game called Kernel Panic [Ker]. The game is a user friendly action-oriented and players conduct the game by writing different commands. The paper evaluated four criteria: enhancement of programming skills; system usability; entertainment; and teachers' assessment. In 2011, L. Goel et al. ${ }^{[13]}$ designed a 3D game called "Second life (SL)" to enhance the ability of learning decision-making topics. SL is a virtual world environment which simulates a telecommunication lab with all contents and avatars are assigned to the students to play different role and interact with others to do their tasks.

Plenty of research have been undertaken in 2012 which show that the SGs have become the center of attention recently. For instance, E. Nunohiro et al. ${ }^{[14]}$ reported the design, implementation, and assessment of the Game-themed programming assignment (GTA) modules for computer programming courses. Each assignment module is designed to be self-contained and include materials for the students. There are seven assignment examples which each one consist of a roleplaying game to improve the introductory programming concepts. N. Adamo-Villani et al. $^{[15]}$ nominated the development and initial evaluation of a serious game that can be used to teach secure coding and Information Assurance (IA) concepts in computing courses. The game consists of seven levels which each one is an engaging IA room with a specific IA concept. By selecting different levels the students are introduced to the concepts by the room robot through narration, text, and images. C. Caulfieldet al. ${ }^{[16]}$ designed "Simsoft" which is a bored-game regarding project management education. The game was on the board and the players gather around it to discuss the current state of their project and to consider their next move. There is also a simple Java-based dashboard to show the players the current and historical state of the project through reports and messages.

\section{Research Methodology}

Herewith, we have carried out a systematic literature review to identify studies on the use of SGs for IT subjects. A systematic literature review is a kind of research methodology that works on a topic or research question, and tries to identify, assess and interpret available empirical studies ${ }^{[17]}$. Kitchenham ${ }^{[17]}$ identified three main steps for conduction systematic literature review: planning the review, conducting the review, and reporting on the review. Same approach is followed in this study and applied Ghapanchi and Aurum's ${ }^{\text {[18] }}$ research methodology as follows: (1) finding research resources; (2) study selection; (3) data synthesis; and (4) presenting the results. 


\subsection{Study selection process}

Based on keyword terms (see Section 3.3), we searched in scientific databases (see Section 3.2) and found 3437 papers as initial screening. We excluded research articles on the basis of their titles (3275 papers excluded; $n=162$ ). In the second stage, we excluded papers based on their abstracts (134 papers excluded; $\mathrm{n}=28$ ). At the final stage we deleted duplicated articles and read the full text (7 articles excluded; $n=21$ ). As a result of these steps, we had 21 relevant papers in which they designed and applied different SG in several IT related topics. Fig. 1 depicts study selection stages used in this study.

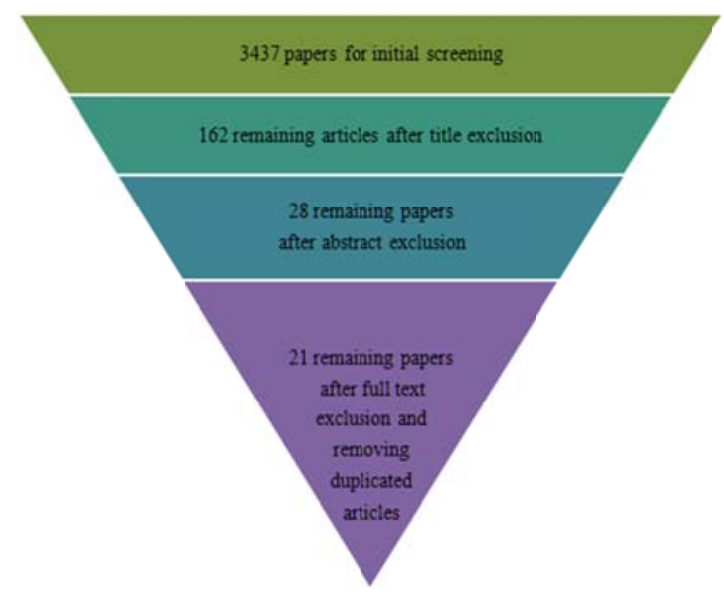

Fig.1. Stages of the study selection process

\subsection{Resource searched}

Eight databases were used to search keywords related to serious games in IT. They are Science Direct, AACE, Editlib, EBSCO, ERIC, SpringerLink, ABI/INFORM Complete and Taylor \& Francis.

\subsection{Search terms}

We used four sets of key words. The first one was the keywords for game (e.g., game, "serious game", "educational game", etc.). The second set included keywords on IT (e.g., "Information technology”, "information system”, "informatics”, “computer”, "computing”, "software" etc.). The third set of keywords was used to focus on studies in higher education (e.g., university, universities, tertiary sector, higher education, etc.). The fourth set of keywords related to teaching and education (e.g., education, educational, educate, teaching, learning, pedagogy, pedagogical, etc.).

\subsection{Inclusion/Exclusion criteria}

The following selection criteria were used: (1) papers which have been published before August 2013, (2) English-language articles, and (3) papers focus on application of SG in IT related subjects. Table 1 shows the number of papers at each stage of the selection process. There were 3437 papers initially, and after title, abstract and full paper exclusion, 21 papers remained.

Table 1. Number of studies in different stages of study selection process

\begin{tabular}{|c|c|c|c|c|c|}
\hline & Database & $\begin{array}{c}\text { Initial } \\
\text { number } \\
\text { of } \\
\text { papers }\end{array}$ & $\begin{array}{l}\text { Remaining } \\
\text { Papers } \\
\text { (Title } \\
\text { Exclusion) }\end{array}$ & $\begin{array}{l}\text { Remaining } \\
\text { Papers } \\
\text { (Abstract } \\
\text { Exclusion) }\end{array}$ & $\begin{array}{l}\text { Remaining } \\
\text { Papers (Full } \\
\text { Paper } \\
\text { Exclusion) }\end{array}$ \\
\hline 1 & $\begin{array}{c}\text { Science } \\
\text { Direct }\end{array}$ & 1,962 & 30 & 11 & 8 \\
\hline 2 & AACE & 4 & 4 & 0 & 0 \\
\hline 3 & Editlib & 3 & 3 & 1 & 1 \\
\hline 4 & EBSCO & 374 & 11 & 4 & 3 \\
\hline 5 & ERIC & 79 & 6 & 2 & 2 \\
\hline 6 & Springer Link & 963 & 15 & 7 & 5 \\
\hline 7 & $\begin{array}{l}\text { ABI/INFOR } \\
\text { M Complete }\end{array}$ & 35 & 7 & 3 & 2 \\
\hline 8 & $\begin{array}{c}\text { Taylor \& } \\
\text { Francis }\end{array}$ & 17 & 5 & 0 & 0 \\
\hline & Total & 3437 & 162 & 28 & 21 \\
\hline
\end{tabular}

\section{Results}

\subsection{Result trend}

This section provides the trend of research on the use of SGs in IT subjects. Fig. 2 presents the distribution of the selected articles per year, which shows an increasing trend over time. In particular, the number of articles significantly increased after 2011. This suggests that the SGs in IT education have caught the attention of researchers and teachers as a major concern in GBL these days. The graph experienced a minor peak in 
2010, then a marginal reduction in 2011 and finally surged rapidly.

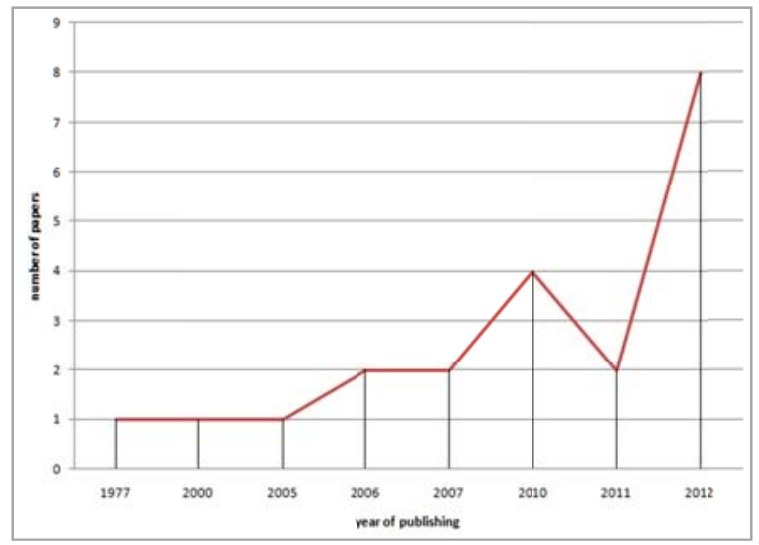

Fig.2.Distribution of the papers over time

Fig. 3provides a breakdown of the frequency of the research papers authored in different continents. It shows that United Kingdom was the most prolific, with $35 \%$ of the papers affiliated with UK universities. This was followed by United State (20\%), and Australia (10\%). All the other countries allocated the same percentage (5\%) of the total which includes Singapore, Canada, India, Japan, Portugal, France and Taiwan. Adoption of SGs for IT subjects seems to be stronger in the UK compared with other countries.

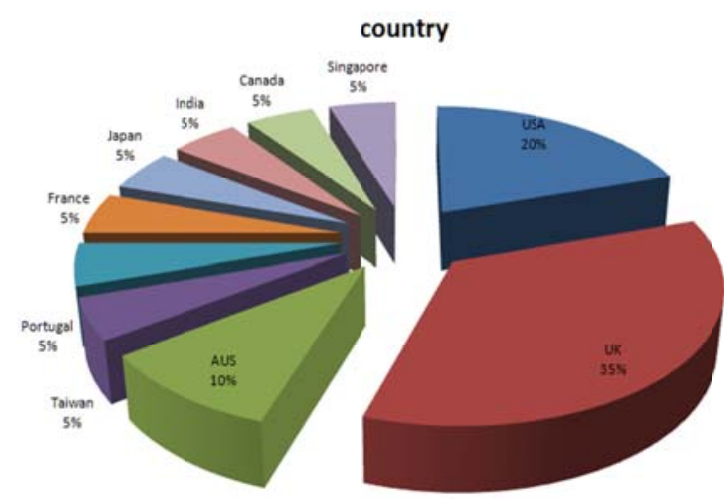

Fig.3. Frequency of the papers per countries

\subsection{Evaluation methods and IT subjects}

Fig. 4 demonstrates that the publications have employed three methods of evaluation to assess their research. The majority of them, about 62\%, applied surveys and questionnaires and 33\% conducted the observation while only $5 \%$ interviewed the participants. In table 2 the name of the journals that our set of studies were published are listed. The distribution is roughly the same but there are 3 articles published in "ProcediaSocial and Behavioral Sciences" Journal. Fig. 5 illustrates different IT subjects which are categorized based on the number of papers that belong to the different subjects. As we can see there are 4 papers in the computer programming filed which shows the importance of SGs in this area and the next attractive topics are IS and computational thinking.

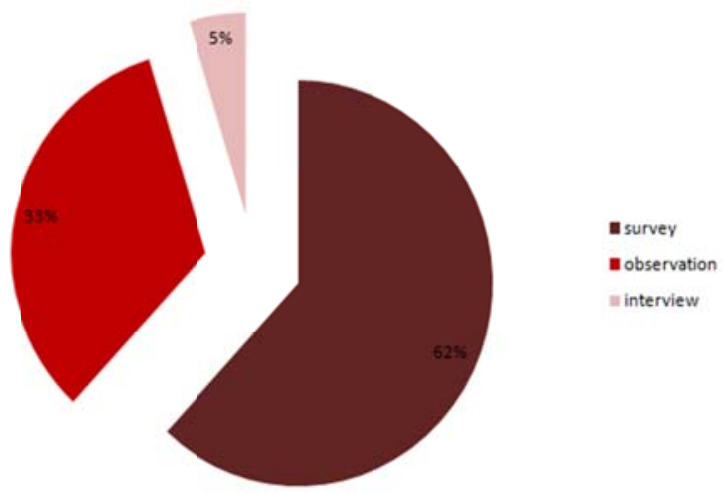

Fig.4.Frequency of different evaluation methods

Table 2.Frequency of the journals

\begin{tabular}{|c|c|c|c|c|}
\hline journal name & Number & journal name & Number \\
\hline $\begin{array}{c}\text { Information } \\
\text { system education }\end{array}$ & 1 & $\begin{array}{c}\text { Simulation \& } \\
\text { Gaming }\end{array}$ & 1 \\
\hline $\begin{array}{c}\text { Decision Support } \\
\text { Systems }\end{array}$ & 2 & $\begin{array}{c}\text { British Journal of } \\
\text { Educational } \\
\text { Technology }\end{array}$ & 1 \\
\hline $\begin{array}{c}\text { Social and } \\
\text { Behavioral } \\
\text { Sciences }\end{array}$ & 3 & $\begin{array}{c}\text { IEEE transactions } \\
\text { on education }\end{array}$ & 1 \\
\hline $\begin{array}{c}\text { Computer } \\
\text { Science }\end{array}$ & 1 & $\begin{array}{c}\text { American society } \\
\text { for information } \\
\text { science and } \\
\text { technology }\end{array}$ & 1 \\
\hline $\begin{array}{c}\text { The Electronic } \\
\text { Journal of e- } \\
\text { Learning }\end{array}$ & 1 & $\begin{array}{c}\text { World Conference } \\
\text { on E-Learning } \\
\text { (ELEARN) }\end{array}$ & 1 \\
\hline $\begin{array}{c}\text { Education and } \\
\text { Information } \\
\text { Technologies }\end{array}$ & 1 & $\begin{array}{c}\text { Book chapter of } \\
\text { HEC Montréal }\end{array}$ & 1 \\
\hline $\begin{array}{c}\text { Computer } \\
\text { Graphics Forum }\end{array}$ & 1 & $\begin{array}{c}\text { educational } \\
\text { technology systems }\end{array}$ & 1 \\
\hline
\end{tabular}


A. Purarjomandlangrudi, A H. Ghapanchi,

Table 2. (Continued)

\begin{tabular}{|c|c|c|c|c|}
\hline $\begin{array}{c}\text { artificial life and } \\
\text { robotics }\end{array}$ & $\mathbf{1}$ & & Computers in Industry & $\mathbf{1}$ \\
\hline $\begin{array}{c}\text { Modern Applied } \\
\text { Science }\end{array}$ & 1 & & Computers \& Education & 1 \\
\hline
\end{tabular}

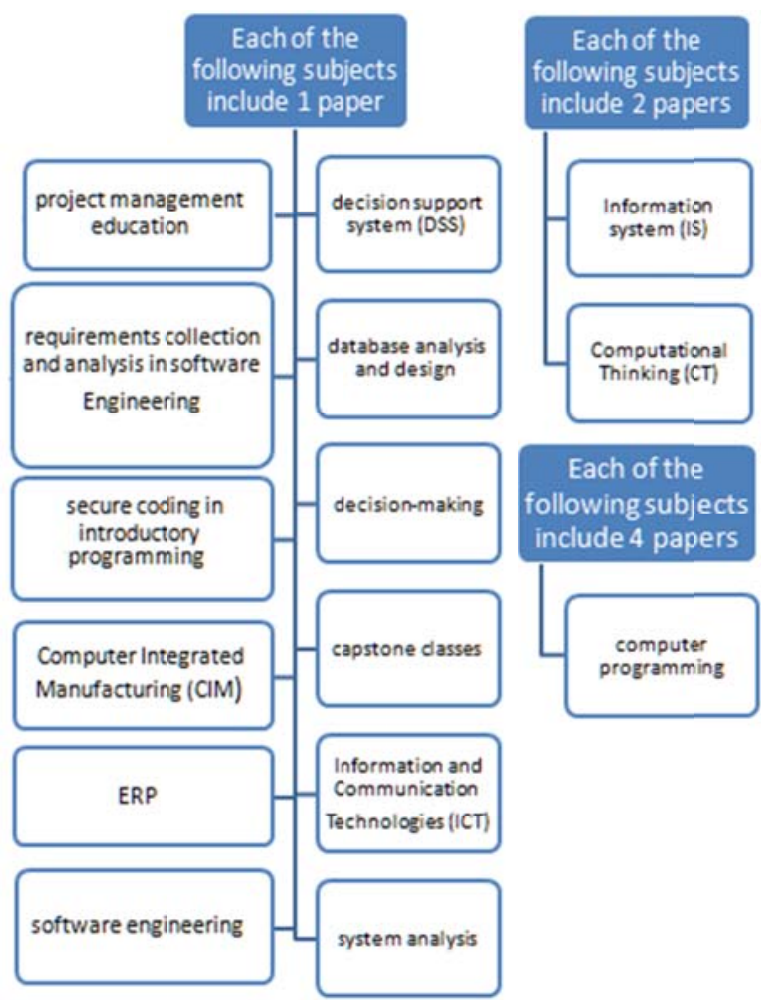

Fig. 5. Various subjects and frequency of games

\subsection{Game classification}

This section categorizes all the games applied in our study. Various types of games are adopted and evaluated through the authors. Some of them are digital such as 3D games or puzzle solving games and some of them are manual like board games. Different classifications could be applied with this regard and various perspectives can be used.We suggest that all the games can be grouped into five categories, namely, Simulation games, Puzzle solving games, Role-play games, Board games, and 3D games. Fig. 6 depicts this assortment very clearly. In the following, all those 21 papers are divided into these clusters and a short description for each of them is provided.

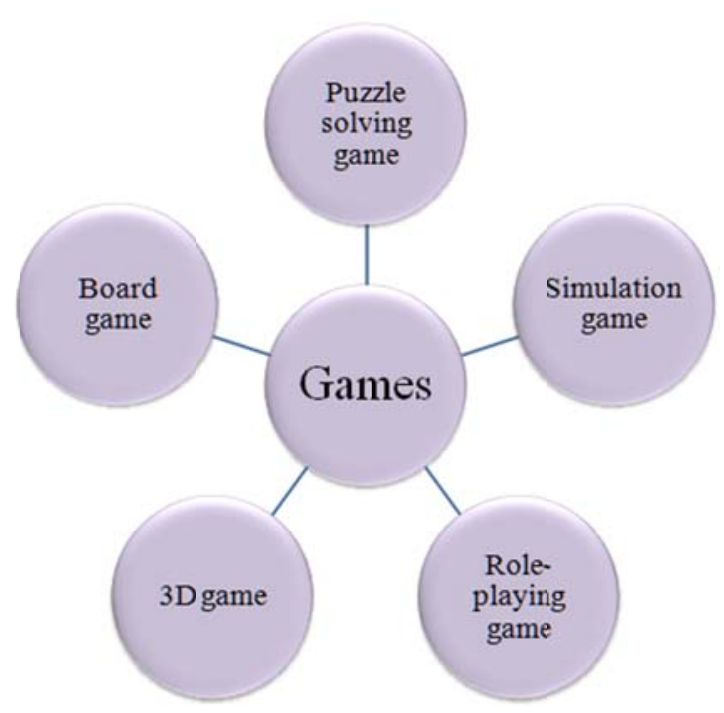

Fig. 6. Five main game categories

\subsubsection{Simulation games:}

A simulation game refers to those types of games which aim to copy several "real life" activities in the form of game for different purposes such as healthcare, education, emergency management, prediction, engineering and so on. In this study it assigns mainly to those kinds of games which attempt to simulate some real experiences for the students to make them think and act as a player to learn different concepts of IT topics. For example in Ref.[19] authors designed and presented a simulation game for requirements collection and analysis in software engineering. The main goal of game is provide the ability of managing and delivering number of software development projects for the teams. The evaluations were done in Higher Education (HE) and Further Education (FE). The results indicate that both groups had found the game very effective and the HE students were more accepting the game, willing to play the game as part of a computing course. Table 3 contains useful information about the articles that applied such games. 
Table 3. Papers that used simulation games

\begin{tabular}{|c|c|c|c|}
\hline NO. & subject & Game name & Highlights of research \\
\hline 1 & DSS & NITOPIA & $\begin{array}{l}\text { The main purpose of the game is to increase students' understanding of strategic } \\
\text { management of international operation. Results: The game gives the student a chance to } \\
\text { practice their own DSS development. The simulation forces them to think for themselves } \\
\text { and generate their own learning and experience the strong useful usage of DSS }{ }^{[9]} \text {. }\end{array}$ \\
\hline 2 & IS & BSG & $\begin{array}{l}\text { The game is consist of six runs and force student to develop formal decision-making } \\
\text { models and affords them the chance to practice the art of decision-making under } \\
\text { uncertainty in a laboratory setting using the aid of DSS. The results showed that the } \\
\text { perceived benefits from using a DSS and user satisfaction are strongly related to } \\
\text { company performance }^{[20]} \text {. }\end{array}$ \\
\hline 3 & $\begin{array}{l}\text { database } \\
\text { design }\end{array}$ & N/A & $\begin{array}{l}\text { There are } 3 \text { levels that form the learning environment: } 1 \text {-online learning units/topics } 2 \text { - } \\
\text { visualizations } 3 \text {-The simulation game. Levels } 1 \text { and } 2 \text { of the environment have been } \\
\text { developed and initial findings are positive. A Chi-squared test using the crosstab } \\
\text { frequencies was conducted and the result showed that a games-based learning } \\
\text { environment can highly impact the learners' skills to understand and perform database } \\
\text { analysis and design }{ }^{[7]} \text {. }\end{array}$ \\
\hline 4 & $\begin{array}{c}\text { software } \\
\text { engineering }\end{array}$ & N/A & $\begin{array}{l}\text { "The basic idea of the game is for the team to manage and deliver a number of software } \\
\text { development projects. Each player has a specific role, such as project manager, systems } \\
\text { analyst, systems designer or team leader". The evaluations were done in Higher } \\
\text { Education (HE) andFurther Education (FE). The results indicate that the game meet the } \\
\text { expectations of HE learners more than the FE learners and regarding perceptions, HE } \\
\text { students were more accepting of the game, willing to play the game as part of a } \\
\text { computing course and found the game more engaging }{ }^{[19]} \text {. }\end{array}$ \\
\hline 5 & CIM & PMSG\&BPSG & $\begin{array}{l}\text { The simulation games were arranged in all cases and they lasted about an hour and after } \\
\text { each session people answered some questions. In the PMSG the life cycle of a generic } \\
\text { one-of-a-kind delivery project is fully simulated with a few duration sample dates of the } \\
\text { project. In the BPSG the main business process chains of the whole company are } \\
\text { simulated at a rough level. The general feedback from the students showed that the } \\
\text { simulation game was very effective in learning the concept of } \mathrm{CIM}^{[4]} \text {. }\end{array}$ \\
\hline 6 & ERP & SAP R/3 & $\begin{array}{l}\text { The business game was conducted with } 30 \text { students distributed among five groups. Each } \\
\text { group is an independent company which is completely responsible for its profits and } \\
\text { losses. All of the students in the companies are involved in the manufacturing and } \\
\text { distribution of muesli cereals to practice the concept of Enterprise Resource Planning. } \\
\text { All teams took part at the presentations and found the game very beneficial. } 93 \% \text { of the } \\
\text { participated students got their SAP certification and it shows how effective it is }{ }^{[8]} \text {. }\end{array}$ \\
\hline 7 & $\begin{array}{l}\text { Knowledge } \\
\text { Management }\end{array}$ & $\begin{array}{l}\text { The Chief } \\
\text { Knowledge } \\
\text { Officer } \\
\text { (CKO) }\end{array}$ & $\begin{array}{l}\text { The goal of CKO is to enhance the experience in which participants could face issues } \\
\text { related to knowledge management and learn how their decisions could affect the } \\
\text { consequence of the company. It is developed in a Microsoft Excel environment and is } \\
\text { coded using Visual Basic and players are grouped into knowledge management teams to } \\
\text { assist the Chief Knowledge Officer of a company to go through eight business cycles of } \\
\text { decision making. The results have confirmed the profitableness and effectiveness of } \\
\text { CKO in teaching and learning knowledge management }{ }^{[6]} \text {. }\end{array}$ \\
\hline
\end{tabular}

\subsubsection{Puzzle-solving games:}

A puzzle is a problem which tests the genius of the solver and usually designed as a form of entertainment but they can also apply in education. As it can be seen from table 4, there are only three papers in this category. First one is for teaching the ICT concepts to physical education and sport science undergraduate students and named "Olympic Games of Athens" which comprise several puzzles which were merged into the storyline perfectly and require the player to get involved in the construction of new knowledge. The second one that called "CAPTAIN3" is for computer programming which is a game for learners to create programs similar to solving a puzzle game. The third one is also related to 
the computer programming where players control a character and help him to reach specific destination points by giving different commands to the character.

Table 4. Papers that used Puzzle-solving games

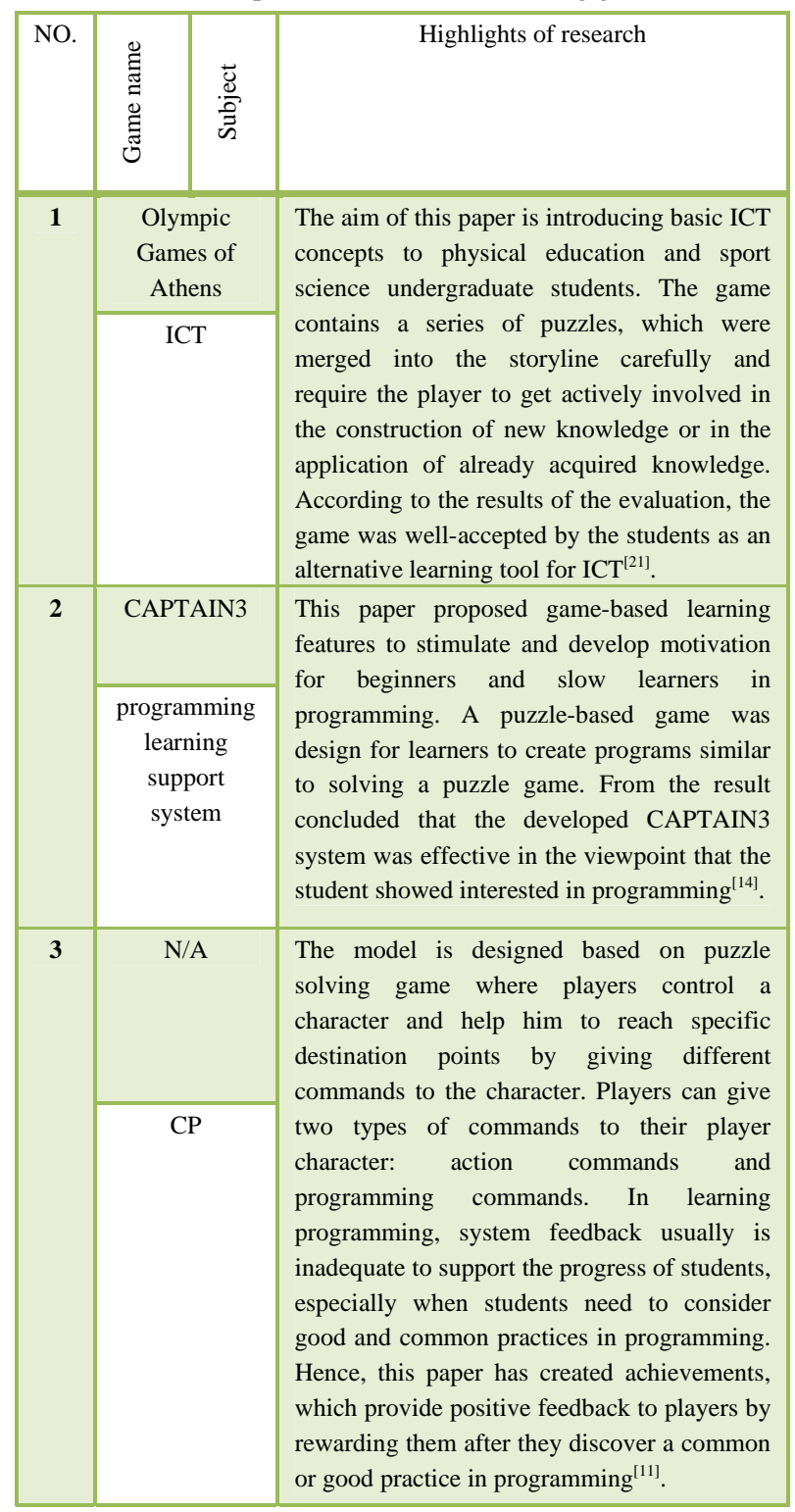

\subsubsection{Board games:}

The third type of games is board game. As its name demonstrates, these games are designed based on a board that players are gathered around the board and follow the story of the games. These games need much preparation in terms of designing and modeling as a tool of education for they have to be engaging and make the students learn and practice several concepts through playing. Table 5 indicates the papers that used the games "Simsoft" and "THE MIS" for teaching software project management and traditional information systems development life-cycle concepts respectively.

Table 5. Papers that used board games

\begin{tabular}{|c|c|c|c|}
\hline NO. & 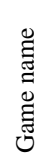 & 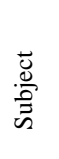 & Highlights of research \\
\hline \multirow[t]{2}{*}{1} & \multicolumn{2}{|c|}{ Simsoft } & \multirow{2}{*}{$\begin{array}{l}\text { The purpose of the research was to explore } \\
\text { how games could contribute to better software } \\
\text { project management education. The game was } \\
\text { on the board and the players gather around it } \\
\text { to discuss the current state of their project and } \\
\text { to consider their next move. There is also a } \\
\text { simple Java-based dashboard to show the } \\
\text { players the current and historical state of the } \\
\text { project through reports and messages. The } \\
\text { findings show that the majority of students } \\
\text { were satisfied by the Simsoft and experienced } \\
\text { learning by doing and found the game very } \\
\text { useful pedagogical tools and are well- } \\
\text { received }{ }^{[16]} \text {. }\end{array}$} \\
\hline & \multicolumn{2}{|c|}{$\begin{array}{c}\text { project } \\
\text { management }\end{array}$} & \\
\hline \multirow[t]{2}{*}{2} & \multicolumn{2}{|c|}{ THE MIS } & \multirow{2}{*}{$\begin{array}{l}\text { The content of the game contains the project } \\
\text { management and traditional information } \\
\text { systems development life-cycle concepts. The } \\
\text { game offers a variety of practical eventualities } \\
\text { of information systems development, such as } \\
\text { disasters, audits, staff turnover, technical } \\
\text { problems, support from the project sponsor, } \\
\text { user resistance, and changes to requirements, } \\
\text { and business mergers. The student feedback } \\
\text { indicates that the MIS game represents an } \\
\text { innovative contribution to the learning of } \\
\text { information systems development concepts } \\
\text { from a management point of view }{ }^{[5]} \text {. }\end{array}$} \\
\hline & \multicolumn{2}{|c|}{ IS } & \\
\hline
\end{tabular}

\subsubsection{Three-Dimensional games:}

By developing the digital technology in recent decades, 3D virtual world has become very popular among the researchers all over the world. The education sector has also benefited from this technology in different purposes particularly in teaching and learning. Table 6 shows the papers which used3D games in terms of teaching the subjects decision-making, system analysis, and also in capstone class. For high ability of imagination, simulation and designing of this technique, it is predicted the number of its users will increase 
substantially and most of classes will be held in a virtual words and every students choose their own avatars instead of physical attendance in near future ${ }^{[13]}$.

\subsubsection{Role-playing games:}

Generally role-playing game refers to those types of games that players assume roles of characters in the game storyline and are responsible for acting out these roles. For instance, the first paper in table 7 is describing a game titled "Program your robot" in which the player helps a robot to escape from a series of platforms by constructing an escape plan called a "solution algorithm". In fact, the player is control the acting of the robot by writing comments. This game was designed for improving the ability of learning Computational Thinking (CT) and introductory programming. M. Muratetet al. ${ }^{[12]}$ introduced "Prog\&Play" game for computer programming which is based on an open source RTS game called Kernel Panic. The game is very user-friendly and participants conduct the game by writing commands. The web links of such games are provided in table 7.

Table 6. Papers that used 3Dgames

\begin{tabular}{|c|c|c|c|}
\hline NO. & $\begin{array}{l}\text { Game } \\
\text { name }\end{array}$ & Subject & Highlights of research \\
\hline 1 & $\overline{S L}$ & $\begin{array}{c}\text { decision- } \\
\text { making }\end{array}$ & $\begin{array}{l}\text { SL is a virtual world environment which simulates a telecommunication lab with all contents and avatars are assigned } \\
\text { to the students to play different role and interact with others to do their tasks. The result and conclusions have shown } \\
\text { that technological specificities of virtual worlds in form of social and context facilitation play a significant role in the } \\
\text { formation of decision-making }{ }^{[13]} \text {. }\end{array}$ \\
\hline 2 & N/A & $\begin{array}{c}\text { capstone } \\
\text { class }\end{array}$ & $\begin{array}{l}\text { The system developed in this paper can help the feasibility ofstudents' game designs by employing DirectX in text } \\
\text { format to manipulate 3D options and taking advantage of Google's free powerful 3Dmodeling tool. This game-base } \\
\text { environment helps students to develop their ability of designing 3D digital virtual worlds }{ }^{[22]} \text {. }\end{array}$ \\
\hline 3 & N/A & $\begin{array}{l}\text { system } \\
\text { analysis }\end{array}$ & $\begin{array}{l}\text { This paper uses 3D game to improve self-efficacy for student's learning and the course content corresponding to the } \\
\text { game level content. The student divided into two group, the experimental group and the control group. the former uses } \\
\text { "game-based learning", and the later uses the "traditional face-to-face learning". The game was simulated an office } \\
\text { environment that the students are different staff who participate the process of system analysis. The results show that } \\
\text { the learning motivations of students have significant impact on the learning achievement, and the learning } \\
\text { achievements of students with game-based learning are better than those who use the traditional face-to-face } \\
\text { teaching }{ }^{[23]} \text {. }\end{array}$ \\
\hline
\end{tabular}

Table 7. Papers that used role-playing games

\begin{tabular}{|c|c|c|c|c|}
\hline NO. & Subject & $\begin{array}{l}\text { Game } \\
\text { name }\end{array}$ & Highlights of research & Web link \\
\hline 1 & $\mathrm{CT}$ & $\begin{array}{c}\text { Program } \\
\text { your robot }\end{array}$ & $\begin{array}{l}\text { The game help a robot to escapefrom a series of platforms by } \\
\text { constructing an escape plan called a solution algorithm. It has six } \\
\text { levels and each one presents a different challenge and aims to teach a } \\
\text { different programming construct. In conclusion this type of approach } \\
\text { can enhance the problem solving abilities of introductory computer } \\
\text { programming student[24]. }\end{array}$ & $\begin{array}{c}\text { www.programyourrobot.com } \\
\text { www.ceebot.com/colobot/index- } \\
\text { e.php } \\
\text { www.robozzle.com. }\end{array}$ \\
\hline 2 & $\mathrm{CT}$ & $\begin{array}{c}\text { Program } \\
\text { your robot }\end{array}$ & $\begin{array}{l}\text { The paper summarized different cognitive skills, characterizing } \\
\text { computational thinking, into five categories and developed these } \\
\text { skills into the context of a digital game. The results show that the } \\
\text { majority of students found the game interesting and provided positive } \\
\text { feedback that they thought this approach could develop the problem } \\
\text { solving abilities of learning introductory programming }{ }^{[25]} \text {. }\end{array}$ & $\begin{array}{c}\text { www.programyourrobot.com } \\
\text { www.ceebot.com/colobot/index- } \\
\text { e.php } \\
\text { www.robozzle.com. }\end{array}$ \\
\hline 3 & $\mathrm{CP}$ & Prog\&Play & $\begin{array}{l}\text { "Prog\&Play is based on an open source real-time strategy (RTS) } \\
\text { game called Kernel Panic [Ker]". The game is a user friendly action- } \\
\text { oriented and players conduct the game by writing different } \\
\text { commands. The paper evaluates four criteria: enhancement of } \\
\text { programming skills; system usability; entertainment; and teachers' }\end{array}$ & $\begin{array}{l}\text { http://www.irit.fr/ProgAndPlay/ } \\
\text { progAndPlay_Installation_en.php }\end{array}$ \\
\hline
\end{tabular}

Published by Atlantis Press

Copyright: the authors 


\begin{tabular}{|c|c|c|c|c|}
\hline & & & $\begin{array}{l}\text { assessment. Through the evaluation it was observed that Prog\&Play } \\
\text { is really appreciated by students and it has helped reduce students' } \\
\text { failure and teachers were very happy with the game and they plan to } \\
\text { continue using Prog\&Play }{ }^{[12]} \text {. }\end{array}$ & \\
\hline 4 & $\begin{array}{l}\text { secure } \\
\text { coding }\end{array}$ & IA game & $\begin{array}{l}\text { The game is for students of introductory computer science course to } \\
\text { learn basic Information Assurance (IA) concepts and secure coding } \\
\text { and the student plays as the main protagonist-Data Detector (DD) } \\
\text { who travels through computer techno-inspired environments (IA } \\
\text { concept rooms) and in each environment learns a different IA } \\
\text { concept. The game consists of seven levels which each one is an } \\
\text { engaging IA room with a specific IA concept. the following results } \\
\text { have been concluded from the evaluation : "1. assess the overall } \\
\text { worth and effectiveness of the program; } 2 \text {. draw out key lessons } \\
\text { learned from the project; and } 3 \text {. determine the sustainability, } \\
\text { transferability, scalability, and relative importance of the initiative in } \\
\text { enhancing students' understanding of secure coding concepts as well } \\
\text { as increase students' retention in computer science majors"[15]. }\end{array}$ & $\begin{array}{l}\text { http://www2.tech.purdue. } \\
\text { edu/cgt/i3/IAgame/website/ }\end{array}$ \\
\hline 5 & $\mathrm{CP}$ & GTA & $\begin{array}{l}\text { The paper represents the design, implementation, and assessment of } \\
\text { the Game-themed programming assignment (GTA) modules. Each } \\
\text { assignment module is designed to be self-contained and include } \\
\text { materials for the students. There are seven assignment examples } \\
\text { which each one consist of a role-playing game to improve the } \\
\text { introductory programming concepts. According to the results the } \\
\text { GTA modules are simple "interactive graphics applications" and aim } \\
\text { to enhance technical concepts rather than the fun-nessof the game }{ }^{[26]} \text {. }\end{array}$ & Table 2. (Continued) \\
\hline 6 & $\begin{array}{c}\text { software } \\
\text { engineering }\end{array}$ & SDSim & $\begin{array}{l}\text { The main idea of the game is for the team to manage and deliver a } \\
\text { number of software development projects. Different role assigned to } \\
\text { the player such as project manager, systems analyst, systems designer } \\
\text { or team leader. The feedbacks indicate that this new games-based } \\
\text { learning application has significantly improve the understanding of } \\
\text { requirements collection and analysis, design and project } \\
\text { management }{ }^{[10]} \text {. }\end{array}$ & \\
\hline
\end{tabular}

\section{Discussion}

According to the trend of research it can be implied that few studies have been undertaken before 2007, but in last two years SGs in IT education has attracted more considerations. It demonstrates that this topic needs more studies by researchers. The greatest number of research on the topic was undertaken in the UK and US while in the Middle East, Africa and South America there is no paper or in Asia the percentage of research was low. In Europe, except UK, the number of papers was zero, it indicates that the researchers from these countries should pay more attention to this area in future. One of the important aspects of executing a research is the evaluation part. Evaluation is a process that critically inspects a program with the purpose of making a judgment about it to enhance the effectiveness. Each of the aforementioned papers used only one of the three methods (survey, observation and interview). Thus there is a lack of research that employs a mix methodology (e.g. mix of interview and observation) to assess the quality and effectiveness of the applied game.

Our classification in terms of game types can contribute to inform IT teachers who are interested in applying a game in their subjects. Fig. 7 depicts the number of papers which were allocated to each game category. Simulation game and role-playing game are at the highest percentage showing that there are more options for teachers to select them in their courses. On the other hand, there are few papers in type of board game or 3D game which implies the lake of research in these areas and the necessity of more researches in future. 


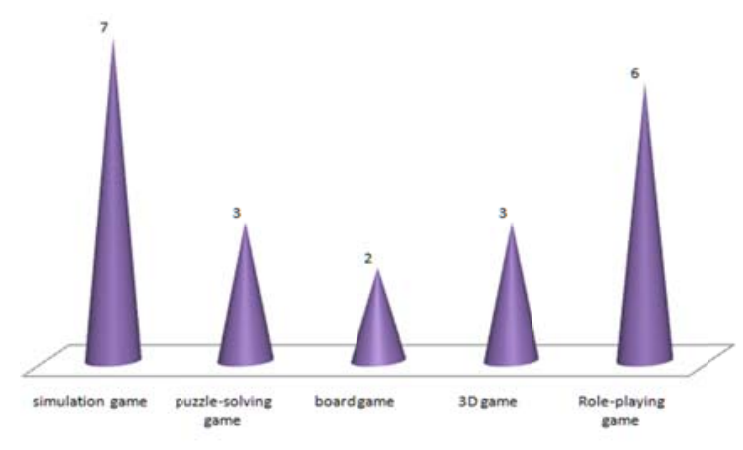

Fig. 7.Distribution of the games

\section{Conclusion}

Using games as an educational tool or in the other words educational serious games have been taken into consideration recently. Particularly in IT subjects, researchers have utilized them to improve the quality of teaching in their courses. However, there is a lack of research in this area which synthesizes the existing body of knowledge and provides a bigger picture of such educational games. This paper studied eight scholarly databases and found 21 articles for further analysis. The applied games were classified based on the nature of their game to five main categories, namely, simulation games, board games, puzzle-solving games, 3D games and role-playing games. The results indicate that in almost all existing studies, students were generally satisfied with such educational games and have found them very effective and useful. They were experiencing 'learning by doing' experiment through playing the games. In some cases like simulation games, the players were involved in projects that provide an environment to them to face the real challenges. It can be concluded that SG is an effective and useful instrument for teaching IT subjects and should be paid special attention by teachers and researchers in future.

\section{References}

1. R. Van Eck, "Digital game-based learning: It's not just the digital natives who are restless," EDUCAUSE review, vol. 41, p. 16, 2006.

2. M. David and C. Sande, "Serious Games: Games That Educate, Train, and Inform," Boston: Thomson Course Technology, 2006.

3. J. Rice, "Assessing Higher Order Thinking in Video Games," Journal of Technology and Teacher Education, vol. 15, pp. 87-100, 2007.
4. T. Savolainen, "Simulation games in CIM and the learning organisation," Computers in industry, vol. 33, pp. 217-221, 1997.

5. A. Martin, "The design and evolution of a simulation/game for teaching information systems development," Simulation \& Gaming, vol. 31, pp. 445-463, 2000.

6. A. Y. Chua, "The design and implementation of a simulation game for teaching knowledge management," Journal of the American Society for Information Science and Technology, vol. 56, pp. 1207-1216, 2005.

7. T. M. Connolly, M. Stansfield, and E. McLellan, "Using an online Games-Based learning approach to teach database design Concepts," The Electronic Journal of e-Learning, vol. 4, pp. 103-110, 2006.

8. P.-M. Léger, Using a simulation game approach to teach ERP concepts: Montréal: HEC Montréal, Groupe de recherche en systèmes d'information, 2006.

9. T. Ben-Zvi, "Using business games in teaching DSS," Journal of Information Systems Education, vol. 18, pp. 113-124, 2007.

10. T. M. Connolly, M. Stansfield, and T. Hainey, "An application of games-based learning within software engineering," British Journal of Educational Technology, vol. 38, pp. 416-428, 2007.

11. C. Kazimoglu, M. Kiernan, L. Bacon, and L. Mackinnon, "Developing a game model for computational thinking and learning traditional programming through game-play," in World Conference on E-Learning in Corporate, Government, Healthcare, and Higher Education, 2010, pp. 1378-1386.

12. M. Muratet, P. Torguet, F. Viallet, and J.-P. Jessel, "Experimental feedback on Prog\&Play: a serious game for programming practice," in Computer Graphics Forum, 2011, pp. 61-73.

13. L. Goel, I. Junglas, B. Ives, and N. Johnson, "Decision-making in-socio and in-situ: Facilitation in virtual worlds," Decision Support Systems, vol. 52, pp. 342-352, 2012.

14. E. Nunohiro, K. Matsushita, K. J. Mackin, and M. Ohshiro, "Development of game-based learning features in programming learning support system," Artificial Life and Robotics, vol. 17, pp. 373-377, 2012.

15. N. Adamo-Villani, M. Oania, and S. Cooper, "Using a Serious Game Approach to Teach Secure Coding in Introductory Programming: Development and Initial Findings," Journal of 
Educational Technology Systems, vol. 41, pp. 107131, 2012.

16. S. P. M. Craig Caulfield, Jianhong (Cecilia) Xia, D Veal, "Shall We Play a Game?," Modern Applied Science, vol. Vol. 6, No. 1, 2012.

17. B. Kitchenham, "Procedures for performing systematic reviews," Keele, UK, Keele University, vol. 33, p. 2004, 2004.

18. A. H. Ghapanchi and A. Aurum, "Antecedents to IT personnel's intentions to leave: A systematic literature review," Journal of Systems and Software, vol. 84, pp. 238-249, 2011.

19. T. Hainey, T. M. Connolly, M. Stansfield, and E. A. Boyle, "Evaluation of a game to teach requirements collection and analysis in software engineering at tertiary education level," Computers \& Education, vol. 56, pp. 21-35, 2011.

20. T. Ben-Zvi, "The efficacy of business simulation games in creating Decision Support Systems: An experimental investigation," Decision Support Systems, vol. 49, pp. 61-69, 2010.

21. R. M. Couceiro, M. Papastergiou, M. Kordaki, and A. I. Veloso, "Design and evaluation of a computer game for the learning of Information and Communication Technologies (ICT) concepts by physical education and sport science students," Education and Information Technologies, pp. 1-24, 2011.

22. M.-S. Kuo and T.-Y. Chuang, "A Time and Cost Effective Approach to 3D Scenario Building in a Digital Game Design Class," Procedia-Social and Behavioral Sciences, vol. 64, pp. 209-218, 2012.

23. C.-H. Cheng and C.-H. Su, "A Game-based learning system for improving student's learning effectiveness in system analysis course," ProcediaSocial and Behavioral Sciences, vol. 31, pp. 669675, 2012.

24. C. Kazimoglu, M. Kiernan, L. Bacon, and L. Mackinnon, "A serious game for developing computational thinking and learning introductory computer programming," Procedia-Social and Behavioral Sciences, vol. 47, pp. 1991-1999, 2012.

25. C. Kazimoglu, M. Kiernan, L. Bacon, and L. MacKinnon, "Learning Programming at the Computational Thinking Level via Digital GamePlay," Procedia Computer Science, vol. 9, pp. 522531, 2012.

26. K. Sung, C. Hillyard, R. L. Angotti, M. W. Panitz, D. S. Goldstein, and J. Nordlinger, "Game-themed programming assignment modules: A pathway for gradual integration of gaming context into existing introductory programming courses," Education, IEEE Transactions on, vol. 54, pp. 416-427, 2011. 